\title{
Impact of International Trade on Economic Growth in Nigeria (1988-2012)
}

\author{
Adeleye J. O. ${ }^{1}$, Adeteye O. S. ${ }^{2}$ \& Adewuyi M. O. ${ }^{3}$ \\ ${ }^{1}$ M Sci Banking \& Finance, ACIB, Nigeria \\ ${ }^{2}$ B Sci. Banking \& Finance, MBA, FCIB, Nigeria \\ ${ }^{3}$ M Sci Banking \& Finance, FCIB, Nigeria \\ Correspondence: Adeteye O. S., B Sci. Banking \& Finance, MBA, FCIB, Nigeria. E-mail: gokeadeteye@yahoo.com
}

Received: February 3, 2015

Accepted: June 18, 2015

Online Published: July 16, 2015

doi:10.5430/ijfr.v6n3p163

URL: http://dx.doi.org/10.5430/ijfr.v6n3p163

\begin{abstract}
The study examines the impact of international trade on economic growth in Nigeria, using net export (i.e total export less total import) and Balance of Payment as proxies for international trade while Gross Domestic Product represent economic growth. The study employed regression analysis as the method of analysis using co-integration and error correction modeling techniques to find the long-run relationship between economic performance and international trade. Only Total Export (TEX) remains positive and significant while others remain insignificant, which means, Nigeria is running a monocultural economy where only oil act as the sole support of the economy without tangible support from other sectors such as industrial/manufacturing and agriculture. The government should therefore pursue aggressive diversification of the economy by putting in place policies and incentives that will boost non-oil export, the manufacturing sector and overall promote the industrial growth of Nigeria.
\end{abstract}

Keywords: total import, total export, gross domestic product, balance of payment

\section{Introduction}

International trade is simply known as the exchange of goods and services between nations of the world. At least two countries should be involved in the activities, that is, the aggregate of activities relating to trading between merchants across borders. Traders engage in economic activities for the purpose of the profit maximization engendered from differentials among international economic environment of nations (Adedeji, 2006).

Theory of comparative advantage make us to understand that countries trade with each other in goods and services because of the concept of differentials in the natural resources, human capital, financial capital and technical capabilities endowment of nations. Some countries are more endowed in these resources than others, even, many countries that are adequately blessed with good resources may not have the ability to manage and channel them to their advantage, hence, denying them the opportunity of achieving the necessary growth, development and good standard of living for their citizenry.

The importance of international trade stems from the fact that no country can produce all goods and services which people require for their consumption largely owing to resources differences and constraints. As a result, this trade relationship suggests that economies need to export goods and services in order to generate revenue to finance imported goods and services which cannot be produced domestically.

However, Nigerian economy has grossly underperformed relative to its economic endowment and her peer nations. With about 37 solid minerals types and a population estimates of over 160 million people, one of the largest gas and oil reserves in the world, the economic performance of the country is rather weak when compared to the emerging Asian countries such as Thailand, Malaysia, China, India and Indonesia and even Brazil. These countries had by far lagged behind Nigeria or at par with Nigeria in terms of GDP per capital in 1970s, but later they were better able to transform their economies to emerge as major players on the global economic arena. In 1970, for instance, Nigeria had a GDP per capital of US $\$ 233.35$ and was ranked $88^{\text {th }}$ in the world, when China was ranked $114^{\text {th }}$ with a GDP per capital of US\$111.82 (Sanusi 2010). Today, China occupied an enviable position even as the second largest economy after the United State of America, largely owing to her self-esteemed trade position. 
This paper seeks to viewing international trade from the perceptive of net export (ie. total export less import) and exchange rate in Nigeria. Economic development is one of the main objectives of every society in the world and economic growth is fundamental to economic development. Export is considered as one of the very important contributors among them.

The debate on the relationship between export expansion and economic growth has exhibited considerable interest in the field of development economics, several empirical studies have been conducted to assess the role of exports in the economic growth of developing countries from various aspects (Miochealy, 1977).

Most of the studies have concluded beneficial effects of export performance on economic growth such as:

1. Increasing specialization and the spillover effects of the export sector's growth

2. Greater capacity utilization

3. The externalities effect of exports in diffusion of modern technology across other sectors and industries and

4. The increasing effects of economies of scale, industrialization and imports of capital goods.

\subsection{Statement of the Problem}

The growth performance of the Nigeria economy has been less satisfactory during the past three decades until recently when statistics shows steady growth in the nation's economy. Apart from oil, Nigeria export mainly primary products and often rely almost exclusively on a limited number of commodities, such exports are characterized by lower prices than manufactured goods plus highly volatile markets. Thus, Nigeria is often on the wrong end of unbalanced trade environment that favours developed countries. Nigeria with the abundant human and natural resources is paradoxically being regarded as one of the poorest countries in the world. Hence, the need to answer some important questions in this research study.

\subsection{Objective of the Study}

The general objectives of the study are:

1. To determine the contribution of international trade to economic performance in Nigeria.

2. To determine whether there is bi-directional relationship between exports and economic growth in Nigeria.

\section{Theoretical Framework}

The basic aim of this work is to attempt to advance on those models which basically discuss the static gains of the international trade (IT)

\subsection{Classical Period}

As far as the interactive between International Trade (IT) and Economic Growth (EG) is concerned, there are two ideas to point out in Smith (1776). On one hand, International Trade made it possible to overcome the reduced dimension of the internal market and, on the other hand, by increasing the extension of the market, the labour division improved and the productively increased. The International Trade would therefore constitute a dynamic force capable of intensifying the ability and skills of workers, of encouraging technical innovations and the accumulation of capital, of making it possible to overcome technical indivisibilities and generally speaking, of giving participating countries the possibility of enjoying Economic Growth (EG).

In turn, Ricardo (1817) presented a dynamic model of EG with three forces and three restrictions, he characterized the progressive states as having high savings, capital accumulation, production, productivity benefits and labour demand forcing the increase of wages and demographic growth. However, in view of the limitations of land, both in quantity and quality, the addition alimentary resources were obtained in condition of decreasing returns, in which the production is absorbed by wages in an increasing proportion, reducing the stimulation of new investment and sooner or later, reaching the "stationary state". IT could delay the fall in the value of profit and apart from the contribution of IT, underestimating the importance of technology, he underestimated the positive effects of IT on technology.

\subsection{Post Classical Period}

International Trade and Growth Classical thought gave way to 'marginalization', from the 1870s onwards, this fact led to a 'new theory' (neoclassical) which for sometime kept the main lines of the evolution of the economy in the long-term away from studies. 


\subsection{Neoclassical International Trade (IT)}

The followers of Ricardo ignored the question of the foundations of comparative advantages and didn't identify factors, resulting from IT, that could raise in a lasting form the rate of EG and its tendency in the long-term. In general, the changes introduced in the Ricardoan theory demonstrated the increase of welfare caused by IT, but ignored eventual gains in the rate of EG. It was in the context of neoclassical general equilibrium that the model of Hecksher (1919) appeared, whose contributions, Samuelson (1948 and 1949) completed in the late 40's. In a rigid analysis of the model, we observe that it permits to advocate the opening of the countries to IT, showing that it is efficient, mutually beneficial and positive for the entire world. However, it limits the analysis to the static gains of welfare.

\subsection{Post Classical Growth}

Post classical economist analyzes the race between the increase of population and economic growth with an uncertain winner. This version gradually disappeared with emergence of post classical economic thought. Mashall (1890) pointed out that "the causes which determine the economic progress of nations belong to the study of international trade'. In effect, the expansion of the market that it represented led to the increase of global production and originated the increase of internal and external economies, which resulted in increasing income for the economy. But although, he understood the importance of those externalities, he also recognized the difficulties of his analytic treatment among his successors, only Young (1928) was concerned with EG when he considered like Smith, that the dimension of the market limited the labour division (and therefore, the productivity). He also examined the inter-relation between industries in the process of EG, the creation of new industries due to specialization resulting from extension of the market, the importance of specialization and standardization in a vast market and influence of the market on technological progress.

Another exception of this period remarkably, was (Shumpeter 1912, 1942 and 1954) who repeated old points of view concerning the tendency of the profit to reach a minimum and the dependency of the rate of EG on capital accumulation. But he went further distinguishing 'invention' (advancement of useful knowledge to production) from 'innovation' (economic activity of exploring that knowledge). Considering the latter as the central element of EG, he described the exigencies for a successful innovation, which included the need for markets opened to the sector.

\subsection{Empirical Literature Review}

The contribution of export growth to economic growth has been tested by different economists using different econometric techniques.

Akanni (2007) examines whether oil exporting countries grow as their earnings on oil rents increases, using PC-GIVEID (Ordinary Least Squares Regression). The result shows that there is a positive and significant relationship between investment and economic growth and also on oil rents. In conclusion, oil rents in most rich oil developing countries in Africa do not promote economic growth.

The impact of income generated from oil export on economic growth in Iran, using Cobs-Douglas production function. Show that the economy of Iran adjusts fast to shocks and there is progress in technology in Iran. Oil exports contribute to real income through real capital accumulation. (Akanni, 2007)

However, when Harrod - Domar theory and Slow's theory of economic growth, Ordinary Least Square Regression and Cobs - Douglas production function were employed to test the impact of crude oil on Nigeria economic performance. Using ordinary least square regression, the result shows that crude oil production contributed to economic growth but have no significant improvement on economic growth of Nigeria.

Akanni (2007) also examined the exports and economic growth nexus in Indonesia employing vector autoregressive (VAR) model. The findings indicate the significance of both exports and economic growth to economy of Indonesia as indicated in GIRF analysis. It was concluded that exports and economic growth exhibits bi-directional cause structure, which is Export Led Growth in long-run and Growth Led Export in short-run.

Gemechu (2002), using co-integration and error correction approach in the regression analysis, examines the policies and test for the relationship between export and economic growth. The result shows that export significantly affected Domestic Product Per Capital estimated around \$3,500 person (Nigeria economy).

Erfani (1999) examined the causal relationship between economic performance and exports over the period of 1965 to 1995 for several developing countries in Asia and Latin America. The result showed the significant positive relationship between export and economic growth. This study also provides the evidence about the hypothesis that exports lead to higher output. 
Vohra (2001) showed the relationship between export and growth in India, Pakistan, the Phillipines, Malaysia, and Thailand for 1973 to 1993 . The empirical results indicated that when a country has achieved some level of economic development, the exports have a positive ad significant impact on economic growth. The study also showed the importance of liberal market policies by pursuing export expansion strategies and by attracting foreign investment.

Balaguer (2002) investigated the empirical linkages between exports and economic growth. The analysis show that more export oriented countries like middle-income countries grow faster than the relatively less export oriented countries. The study also showed that export promotion does not have any significant impact on economic growth for low and high income countries.

Balaguer (2002) also examined the hypothesis of export - led growth from the Spanish trade liberalization process initiated four decades ago, for 1961 to 2000. Both the export expansion and the progression from 'traditional' exports to manufactured export are considered for this purpose. It is proved that the structural transformation in export composition has become a key factor for Spain's economic development along with the relationship between export and real output.

Njikam (2003) determined the role of exports in economic growth by analyzing Namibia's data from 1968 to 1992. Results explained the general importance of exports, but do not find discernible sign of accelerated growth because of exports.

Lin (2003) stated that ten percent increase in exports cause one percent increase in GDP in the 1990s in China on the basis of new proposed estimation method, when both direct and indirect contributions are considered.

Shiraz (2004) studied the short run and long run relationship among real export, real import and economic growth on the basis of cointegration and multivariate Granger causality for the period 1960 to 2003. This study showed a long-run relationship among import, export and economic growth and found unidirectional causality from export to output but did not find any significant causality between import and export.

Mah (2005) studied the long-run causality between export and growth with the help of significance of error correction term, ECt-1. This study also indicated that export expansion is insufficient to explain the patterns of real economic growth.

Tang (2006) stated that there is no long run relationship among export, real Gross Domestic product and imports. This study further shows no long-run and short-run causality between export expansion and economic growth in China on the basis of Granger causality which economic growth does Granger-cause imports in the short run.

Pazim (2009) tested the validity of export-led growth hypothesis in three countries by using panel data analysis. It is concluded that there is no significant relationship between the size on national income and amount of export for these countries on the basis of one-way random effect model. The panel unit root test shows that the process for both GDP and Export at first difference is not stationary while the panel co integration test indicates that there is no co integration relationship between the export and economic growth for these countries.

\subsection{Export and Economic Growth}

The relationship between export performance and economic growth has been the focal attention of development economists and will continue to generate controversies as to whether or not export growth performance has a significant impact on economic growth of a nation.

Awoluse (2008) argued that an increase in foreign demand for domestic exportable poroducts can cause an overall growth in output via an increase in employment and income in the exportable sectors.

Balassa (1985) and Erfani (1999), discussed how exports can provide foreign exchange which is critical to imports of capital and intimidate goods that in turn raise capital formation beneficial for meeting expansion of domestic production and thus stimulate output growth.

According to Helpman and Krugman (1985), international trade promotes specialization in production of exports products which in turns boosts the production level, and causes general level of skills to rise in the export sector.

According to Feder (1982), export leads to relocation of resources from the inefficient non-trade sector to the trade sector and dissemination of the new management styles and production techniques through the whole economy.

Giles and Williams (2002) said that the entire economy would benefit due to the dynamic spillover of the export sector growth, and that an increase on exports improves the balance of payment and enlarges the increase of investment goods import and facilities necessary for the domestic production growth. 
Jung and Marshal (1985), argue that growth in real gross national product (GNP) is necessary for the following reasons:

- $\quad$ Export growth may represent an increase in the demand for the country's output and thus serve to increase real GNP.

- An increase in exports may loosen a binding foreign exchange constraints and allow increase in productivity in intermediate imports and hence in the growth of output, and lastly

- $\quad$ Export may result in enhanced efficiency and thus may lead to greater output.

\subsection{Export - Led Growth and Economic Growth}

Theoretically, export-led growth appears among neoclassical economist after the victorious story of newly industrialized Asian countries. They argue that, for instance, Taiwan, Hong-Kong, Singapore and Korea, (the four Asian Tigers), have been successful in achieving high and persistent rates of economic growth since early 1960s; because of their free-market, outward economies (World Bank, 1984).

However, the authenticity of the tigers does not support the analysis. The production and composition of export was not left to the market but resulted as much from carefully planned intervention by the governments. As Amsden (1989) analyzed that the philosophy behind the emergence of this new 'Asian Tigers' is strong, which has deliberately and abundantly provided tariff subsidies and significantly increase export volumes on their own for the following reasons:

1. A limited number of commodities are available for export, so export sectors depend on international developments affecting the world market. An example is the falling price of cotton and base metals that are a major part of export earnings for Central Asia.

2. Industrial production of goods is limited by the lack of downstream activities which does not allow enterprises to produce differentiated products for export or provide some form of export diversification.

3. There is dependence on one or two key export markets and supply sources, and this does not give enterprises an opportunity to develop products according to the standards of more developed markets. This also results in lack of knowledge about marketing abroad.

4. Enterprises lack export readiness, which might be due to unwillingness to venture overseas because the domestic market offers comfort and security. However, the transition to a market economy may force enterprise to look beyond the domestic market in order to earn much-needed foreign exchange and generate employment. International marketing is a much more complicated process than marketing and selling in a domestic economy.

Transitional economies need a lead agency to drive the effort towards becoming exporters. At industry level, two kinds of export dimensions to consider are:

(a) Increasing the export of existing products and

(b) Developing new exportable products.

Increasing the exports of existing products means looking at what industries currently produce for export to the world market. For many transitional and emerging economies, exports are mainly commodity and primary products. Therefore an initial export strategy should focus on enhancing and consolidating the volume of export into existing markets as well as diversifying to other exports markets (Boltho, 1996)

The second dimension involves making an assessment of what new products could be developed for export markets. These new products often originate from spin-offs or downstream activities from existing core industries. For example, the oil industry supports petrochemical industries and oil equipment manufacturing.

\section{Research Methodology}

\section{Introduction}

The major method of analysis employed in this project is the regression analysis. However, since time series variables were applied, it is essential to examine their properties so as not to end up with a spurious regression, which is modeling the relationship among stationary series. Therefore, all variables are examined through their time plots, unit root tests and co integration analysis. 


\subsection{Model Specification}

In line with the above discussion, using co-integration and error correction modeling technique to find the long-run relationship between Economic Performance and International Trade in Nigeria. Following Feder (1982), where Economic Growth proceeded from the effects of exporter sector performance and Solow (1957) that used the function of aggregate production as a starting point to measure the sources of Economic Growth in the United States. These models were modified and specified as follow:

$$
\mathrm{GDP}=\mathrm{f}(\mathrm{BOT}, \mathrm{TIM}, \mathrm{TEX}, \mathrm{BOP}, \mu \mathrm{t})
$$

Where:

$$
\begin{aligned}
\text { GDP } & =\text { Gross Domestic Product } \\
\text { BOT } & =\text { Balance of Trade } \\
\text { TIM } & =\text { Total Import } \\
\text { TEX } & =\text { Total Export } \\
\mathrm{BOP} & =\text { Balance of Payment } \\
\mu \mathrm{t} & =\text { Error term }
\end{aligned}
$$

Equation 3.1 is Linearized as follows:

$$
\mathrm{GDP}=\Omega_{0}+\Omega_{1} \mathrm{BOT}+\Omega_{2} \mathrm{TIM}+\Omega_{3} \mathrm{TEX}+\Omega_{\mathrm{a}_{4} \mathrm{BOP}}+\mu_{\mathrm{t}}
$$

While apriori expectation will be given as

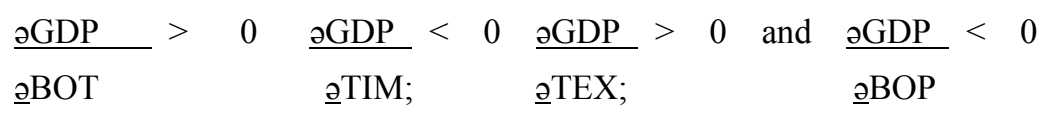

In line with the preceding discussion and assuming a logarithmic relationship equation 3.2 will be re-written as:

$$
\operatorname{LogGDP}=\Omega_{0}+\Omega_{1} \text { BOT }+\Omega_{2} \operatorname{LogTIM}+\Omega_{3} \operatorname{LogTEX}+\Omega_{4} \log \text { BOP }+\mu \mathrm{t}_{\mathrm{t}}
$$

The use of logarithms in this model rather than the raw data in the levels can be justified on ground of both statistical and economic theories. Given that this dispersion of time series increases with the level of the series, it follows that the standard deviation of the series is proportional to its level, also data expressed in terms of logarithms are pruned and definite.

\subsection{Analysis and Empirical Results}

\section{Unit Root Test Results}

The unit root test is conducted on all the variables purposely to determine whether the variables were stationary or not and determine the order of integration (the stationary level) using the Augmented Dickey-Fuller (ADF) test. The table below shows the unit root test result.

Table 1. Augmented Dickey-Fuller (ADF) Unit Root Test

\begin{tabular}{llllll}
\hline Variables & Coefficients & $\begin{array}{l}\text { Mackinnon } \\
5 \%\end{array}$ & Value at & Probability & $\begin{array}{l}\text { Remark on order of } \\
\text { Cointegration }\end{array}$ \\
\hline GDP & -4.9502 & -3.0049 & & 0.0007 & $1(2)$ \\
\hline BOT & -3.9371 & -2.9810 & & 0.0059 & $1(1)$ \\
\hline TIM & -4.1171 & -3.0049 & 0.0000 & $1(2)$ \\
\hline TEX & -4.6509 & -2.9810 & & 0.0010 & $1(1)$ \\
\hline BOP & -3.2326 & -2.9763 & & 0.0289 & $1(0)$ \\
\hline
\end{tabular}

Source: Author's Computations

The Augmented Dickey-Fuller (ADF) unit root test for all the variables is presented in table 1 above

The result shows that only a variable is stationary at level. Two other variables became stationary at first difference while the remaining two were differenced twice to obtain stationary.

Since the results of the variables are found to be stationary at different levels it is necessary to proceed to co integration test. 
Table 2. Engle Granger co integration test of variables

Dependent Variable: ECM

Method: Least Squares

Date: 08/24/14 Time: 22:01

Sample: 1985-2012

Included observations: 28

\begin{tabular}{lllll}
\hline Variable & Coefficient & Std. Error & t-Statistic & Prob. \\
\hline $\mathrm{C}$ & -0.023405 & 0.056062 & -0.417477 & 0.6798 \\
\hline @TREND & -0.001734 & 0.003564 & 0.6307 \\
\hline R-Squared & 0.009021 & Mean dependent var & $4.59 \mathrm{E}-15$ \\
\hline Adjusted R-Squared & -0.029093 & S.D. dependent var & 0.150149 \\
\hline S.E. of regression & 0.152318 & Akaike info criterion & -0.8656948 \\
\hline Sum Squared resid & 0.603217 & Schwarz criterion & -0.761791 \\
\hline Log likelihood & 13.99728 & Hannan-Quinn criter. & -0.827858 \\
\hline F-Statistic & 0.236686 & Durbin-Watson stat & 1.722090 \\
\hline Prob(F-Statistic) & 0.630686 & & \\
\hline
\end{tabular}

Source: Author's' Computations

The variables are found to be co integrated since t-statistics value of 0.4175 and 0.4861 are greater than the coefficients of the variables of 0.0234 and 0.0017 at constant and at trend

3.3 The Long-Run Model Equation Is presented as Follows

$\operatorname{LogGDPt}=-0.00000021 \mathrm{BOT} \mathrm{t}-2.4817 \log \mathrm{TIMt}+1.7555 \log \mathrm{TEXt}-0.00000027 \mathrm{BOPt}$

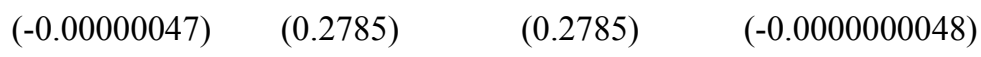

From the above long-run equation, the standard error of each coefficient is reported immediately under the coefficient in brackets. The equation conforms to a-priori expectation. The implication is that a unit increase in Total Import (TIM) will decrease Economic Growth (GDP) by 2.48 units while a unit increase in Total Export (TEX) will increase Economic Growth by 1.76 units. Both BOT and BOP exact only negligible negative impact on the Economic Growth.

The Short Run Model Equation is presented as follows:

Table 3. Overparametrised model

Dependent Variable: DLOG (GDP)

Method: Least Squares

Date: 08/25/14 Time: 01:50

Sample (adjusted): 1988-2012

Included observations: 25 after adjustments

\begin{tabular}{lllll}
\hline Variable & Coefficients & Std.Error & t-Statistic & Prob. \\
\hline $\mathrm{C}$ & 0.161695 & 0.075465 & 2.142656 & 0.0608 \\
\hline $\mathrm{D}(\mathrm{BOT})$ & $-1.66 \mathrm{E}-08$ & $5.99 \mathrm{E}-08$ & -0.277646 & 0.7876 \\
\hline $\mathrm{D}(\mathrm{BOT}(-1))$ & $-7.16 \mathrm{E}-08$ & $6.45 \mathrm{E}-08$ & -1.110220 & 0.2957 \\
\hline $\mathrm{D}(\mathrm{BOT}(-2))$ & $1.98 \mathrm{E}-08$ & $5.25 \mathrm{E}-08$ & 0.377739 & 0.7144 \\
\hline DLOG(TIM) & 0.005721 & 0.123318 & 0.046396 & 0.9640 \\
\hline DLOG(TIM(-1)) & -0.168859 & 0.213887 & -0.789476 & 0.4501 \\
\hline DLOG(TIM(-2) & -0.105789 & 0.166759 & -0.634383 & 0.5416 \\
\hline DLOG(TEX) & 0.419704 & 0.117611 & 3.568567 & 0.0060 \\
\hline DLOG(TEX(-1)) & 0.079867 & 0.135719 & 0.588473 & 0.5707 \\
\hline DLOG(TEX)(-2) $\}$ & 0.069807 & 0.159107 & 0.438745 & 0.6712 \\
\hline
\end{tabular}




\begin{tabular}{lllll}
\hline $\mathrm{D}(\mathrm{BOP})$ & $-7.59 \mathrm{E}-09$ & $2.68 \mathrm{E}-08$ & -0.283630 & 0.7831 \\
\hline $\mathrm{D}(\mathrm{BOP})(-1))$ & $-1.49 \mathrm{E}-08$ & $2.10 \mathrm{E}-08$ & -0.710966 & 0.4915 \\
\hline $\mathrm{D}(\mathrm{BOP})(-2))$ & $3.30 \mathrm{E}-09$ & $3.02 \mathrm{E}-08$ & 0.109056 & 0.9156 \\
\hline DLOG(GDP(-1)) & 0.040187 & 0.297077 & 0.135274 & 0.8954 \\
\hline DLOG(GDP(-2)) & -0.103970 & 0.226011 & -0.460022 & 0.6564 \\
\hline DLOG(GDP(-2) & -0.103970 & 0.226011 & -0.460022 & 0.6564 \\
\hline ECM(-1 & -0.639492 & 0.299191 & -2.137407 & 0.0613 \\
\hline R-squared & 0.878034 & mean dependent var & & 0.213872 \\
\hline Adjusted R-squared & 0.6747757 & S.D. dependent var & & 0.165478 \\
\hline S.E. of regression & 0.094372 & Akaike info criterion & -1.624792 \\
\hline Sum squared resid & 0.080155 & Schwarz criterion & -0.844712 \\
\hline Log likelihood & 36.30990 & Hannan-Quinn criterion & -1.408431 \\
\hline F- static & 4.319398 & durbin-Watson stat & \\
\hline Prob(F-statistic & 0.016027 & & \\
\hline
\end{tabular}

The speed of adjustment is the coefficient of the error correction variable. This indicates that 64 percent departure from the long-run equilibrium is corrected in the short-run. The ECM(-1) is highly significant. The coefficient of ECM -0.639492 suggest fast adjustment. Nearly 64 percent of the disequilibrium of the previous year's shock adjusts back to the long-run equilibrium in the current year.

The results showed that the error correct term ECM(-1) is correctly specified. It satisfies a-priori expectations and statistically significant at the five percent level. The negative sign confirms our earlier conclusion that Economic growth and its regressors (variables of international trade) are indeed cointegrated, and the statistical significance of the error correction term implies disequlibrium in the long-run. The coefficient of the ECM(-1) is -0.693242 and it implies high speed of adjustment from shocks (variables of international trade) are indeed cointegrated, and the statistical significance of the error correction term implies disequilibrium in the long-run. The coefficient of the ECM(-1) is -0.693242 and it implies high speed of adjustment from shocks in the short-run to long-run equilibrium. It also means that 64 percent of the disequilibrium in the previous year adjusts back to equilibrium in the current year.

The equation's standard error of 0.094372 implies that about two-thirds of the time, the predicted value of GDP would be within 9.44 percent of the actual value. The Durbin Watson statistics of 1.739 falls within the 'No serial autocorrelation' region. The model passes the diagnostic test. The ECM variable is properly signed and statistically significant at the five percent level of significance. Therefore, we reject the null hypothesis that the error terms are not normally distributed. This suggests that the ordinary least square estimation is unbiased, has minimum variance, consistent and follows a normal distribution.

Table 4. Parsimonious Model

The over parameterized equation was obtained from Table 2 above and the insignificant variables were deleted with the aid of AIC to obtain the parsimonious model as presented in table 3 below.

Dependent Variabel: DLOG (GDP)

Method: Least Square

Date: 08/26/14 Time: 5=05:23

Sample(adjusted): 1988-2012

Included observations: 25 after adjustments

\begin{tabular}{lllll}
\hline Variable & Coefficient & Std. Error & t-Statistic & Prob. \\
\hline D(BOT(-1)) & 0.144630 & 0.035708 & 4.050388 & 0.0008 \\
\hline DLOG(TIM(-1)) & $-4.00 \mathrm{E}-08$ & $2.72 \mathrm{E}-08$ & -1.469664 & 0.1599 \\
\hline DLOG(TIM(-2)) & -0.108710 & 0.068646 & -1.583627 & 0.1317 \\
\hline DLOG(TEX) & 0.417380 & 0.044085 & 9.467554 & 0.0000 \\
\hline DLOG(TEX(-2)) & 0.062961 & 0.056685 & 1.110719 & 0.2822 \\
\hline D(BOP(-1)) & $-1.24 \mathrm{E}-08$ & $1.38 \mathrm{E}-08$ & -0.899488 & 0.3810 \\
\hline
\end{tabular}




\begin{tabular}{|c|c|c|c|c|}
\hline $\operatorname{ECM}(-1)$ & -0.610623 & 0.181144 & -3.370925 & 0.0036 \\
\hline R-squared & 0.853558 & Mean dependent var & & 0.213872 \\
\hline Adjusted R-squared & 0.793259 & S.D. dependent var & & 0.165478 \\
\hline S.E. of regression & 0.075241 & $\begin{array}{ll}\begin{array}{l}\text { Akaike } \\
\text { criterion }\end{array} & \text { infor } \\
\end{array}$ & & -2.081909 \\
\hline Sum squared resid & 0.096240 & Schwarz criterion & & -1.691868 \\
\hline Log likelihood & 34.02386 & $\begin{array}{l}\text { Hannn-Quinn } \\
\text { criterion }\end{array}$ & & -1.973728 \\
\hline F-statistic & 14.15531 & Durbin-Watson stat & & 1.534927 \\
\hline Prob(F-statistic) & 0.00006 & & & \\
\hline
\end{tabular}

The adjusted R2 used in measuring the goodness of fit of the model is satisfactory. About 79 percent of the variation in the dependent variable (GDP) is explained by joint effect of all the regressors (BOT(-1), TIM(-1), TIM(-2), TEX $(-2)$ and BOP(-1) in the model and is a good fit. The explanatory power of the model is satisfactory.

The F statistics of 14.1553 used in measuring the joint significant of all the independent variables in the model is statistically significant and is a good fit. The standard error value of 0.07524 means that about two-third, of the time, the expected value of the dependent variable will be within 7.52 percent of the actual value. The model passes the diagnostic and normality test.

Export impacts positively and significantly on economic growth. This is in line with a priori expectations. Moreover, one percent rise in export will bring about 41.74 percent in GDP. All other variables beside export bear insignificant negative impact on economic growth. This contradicts a priori expectations.

We therefore reject the null hypothesis that error terms are not normally distributed. This means that the ordinary least square estimator is unbiased, consistent and has minimum variance. The Durbin Watson Statistics of 1.535 falls within the inconclusive region of no serial correlation region. In the parsimonious model, TEX in the two lag period impacts positively but insignificantly on economic growth.

\section{Summary and Conclusion}

From the results obtained, international trade is playing a major role in economic growth of Nigeria but then, of all the variables applied as proxies to international trade, only Total Export (TEX) remains positive and significant while others remain insignificant. This indicates a major problem in the economy of the nation examined. This is also confirmed from the fact that trade balance is insignificant. The cause of the problem therefore is the existence of monoculture where only oil acts as the sole support of the economy at large without tangible support from other sectors such as industrial, manufacturing, agriculture.

Moreover, import offered a negative impact on the economy. This indicates that the position of oil export only cannot effectively shield the excessive and detrimental influence of importation on the economy. Obviously, import exceeds export; this explains why balance of payment as well remain negative in the results obtained.

\subsection{Policy Recommendation}

It is recommended therefore that government at all tiers should embark on holistic policies and approach that will boost the position of non oil exports in Nigeria, especially those that have to do with manufacturing and industry.

Furthermore, it is suggested that there should be an allowance for policies that allow access to a wider base of technological knowledge, it makes technological diffusion easier, it motivates research and avoids redundancies in research.

It is as well recommended that the LDCs open to the foreign investment with more advanced technology so that they could register increases in the rate of innovation and in the economy's rate of growth.

Dependency on import goods both at domestic and industrial production level should be discouraged with the aim of embarking on import substitution approach to economic development in Nigeria.

\section{References}

Adedeji, S. (2006). Writing and Research Proposal in G.O. edu.uI.ng/so Adedeji

Akanni, O.P. (2007). Oil Wealth and Economic Growth in Oil Exporting Countries, AERC Researcg Oaoer 170. 
Amsden, B. (1989). Economc Growth, Export and External Causality: “The Case of African Countries". Applied Economists, 38, 21-27.

Awoluse. (2008). Economic Growth in the Presence of FDI. Retrieved from www.uk.essay.com

Balaguer, M. (2002, October). Exports and Economic Growth in Bangladesh. Journal of Development Studies, 35(1), 89-114

Balassa, B. (1985, June). Exports Policy Choices and Economic Growth in developing countries after the 1973 oil shock. Journal of Development Economics, 4(1), 23-35.

Boltho, A. (1996, July). Was Japanese Growth-Export-Led? Oxford Economic Papers, 48(3), 415- 32.

Erfani, H.S. (1999). Exports, Imports and Economic Growth in Semi-industrialized countries. Journal of Development Economics, 35, 93-116.

Feder, G. (1982, February/April). On "Export and economic Growth". Journal of Development Economics, 12(2), 59-73.

Gemechu, G. (2002). Exports and Economic Growth in Ethiopia - Addis Ababa. Retrieved from University.etd.auu.edu.et/displace/bitsream/123

Giles and William. (2002). "Export Led Growth" A Survey of the Empirical, University of Victoria. Retrieved from web.uvic.ea.8080/./ewpoo2pdf

Helpman, E., \& Krugman, P. (1985). Market Structure and Foreign Trade: Increasing returns, Imperfect Competition and International Economy. Cambridge, Mass: MIT Press.

Jung and Marshal. (1985, May). Exports, Growth and Causality in Developing Countries. Science Direct, 18, 1-12.

Lin, F.C. (1995, July). Export - led Growth and the four little Dragons. Journal of International Trade and Economic Development, 4(2), 203-15.

Marshall, A. (1890). Principle of Economies. London: Macmillan Publishers Limited.

Mah, M. (2005, March). Exports and Growth: An Empirical Investigation. Journal of Development Economics, 4(1), 49-54.

Njikam, D. (2003). Exports and Economic Growth in Sub-Sahara Africa: Is there a Connection? Faculty of Economics \& Management, University of Yaounde - 11 Yaounde.

Pazim. (2009). Growth and Export Expansion in Developing Countries. Journal of Development Economies, 12(3).

Ricardo, (1817). The Principle of Political Economy and Taxation.

Samuelson, P.A. (1948 \& 1949). International Trade and the Equalization of Factor Prices. Economic Journal, 55, 163-184.

Sanusi, L.S. (2010). Banks in Nigeria and National Economic Development; A critical review. Seminar on Becoming an economic driver while applying banking regulation, CIBN, Lagos.

Smith, A. (1776). An Enquiry into the nature of causes of wealth of the Nation. Gulbenklam, Lisbon.

Schumpeter, J. (1912). The Theory of Economic Development. Cambridge: Mass publisher Ltd.

Shumpeter, J. (1942). Capitalism, Socialism and Democracy. New York, Harper and Row.

Shumpeter, J. (1954). History of Economics Analyst. New York: Oxford University Press Ltd.

Shiraz. (2004). Exports and Economic Growth in Asian NICS" an Econometric Analysis for Korea. Applied Economics, 26(1994), 41-51.

Solow, R. (1957). Technical Progress and Aggregate Production Function. Review of Economic Studies, 39, 312-320

Tang, J. (2006). Exports Revenue as Determinant of Economic Growth: Evidence from Botswana. University of Botswana, Botswana.

Vohra. (2001). Exports and Economic Growth in Developing Countries. Evidence from Time Series and Cross-Section Data. Journal of Economic Development and Cultural Change, 36, 51-72.

World Bank. (1984). Industrial Policy and Performance, World Bank Independent Management Consulting Service Regional Case Studies on Access to the European Union Market for Goods and Services: Zambia Report.com ESAi Lusaka.

Young, A. (1928, Dec.). Increasing Returns and Economic Progress. Economic Journal, 38, 527-542. 